\title{
The functional expression of extracellular calcium-sensing receptor in rat pulmonary artery smooth muscle cells
}

\author{
Guang-wei Li ${ }^{1,2+}$, Qiu-shi Wang ${ }^{5 \dagger}$, Jing-hui Hao ${ }^{2}$, Wen-jing Xing ${ }^{2}$, Jin Guo ${ }^{2}$, Hong-zhu Li ${ }^{2}$, Shu-zhi Bai ${ }^{2}$, Hong-xia Li ${ }^{2}$,
} Wei-hua Zhang ${ }^{2,4}$, Bao-feng Yang ${ }^{3,4}$, Guang-dong Yang ${ }^{6}$, Ling-yun Wu ${ }^{2,6}$, Rui Wang ${ }^{2,6}$, Chang-qing $X u^{2,4^{*}}$

\begin{abstract}
Background: The extracellular calcium-sensing receptor (CaSR) belongs to family C of the G protein coupled receptors. Whether the CaSR is expressed in the pulmonary artery (PA) is unknown.

Methods: The expression and distribution of CaSR were detected by RT-PCR, Western blotting and immunofluorescence. PA tension was detected by the pulmonary arterial ring technique, and the intracellular calcium concentration $\left(\left[\mathrm{Ca}^{2+}\right]_{i}\right)$ was detected by a laser-scanning confocal microscope.
\end{abstract}

Results: The expressions of CaSR mRNA and protein were found in both rat pulmonary artery smooth muscle cells (PASMCs) and PAs. Increased levels of $\left[\mathrm{Ca}^{2+}\right]_{\circ}$ (extracellular calcium concentration) or $\mathrm{Gd}^{3+}$ (an agonist of CaSR) induced an increase of $\left[\mathrm{Ca}^{2+}\right]_{i}$ and PAs constriction in a concentration-dependent manner. In addition, the abovementioned effects of $\mathrm{Ca}^{2+}$ and $\mathrm{Gd}^{3+}$ were inhibited by U73122 (specific inhibitor of PLC), 2-APB (specific antagonist of $\mathrm{IP}_{3}$ receptor), and thapsigargin (blocker of sarcoplasmic reticulum calcium ATPase).

Conclusions: CaSR is expressed in rat PASMCs, and is involved in regulation of PA tension by increasing $\left[\mathrm{Ca}^{2+}\right]_{\mathrm{i}}$ through G-PLC-IP 3 pathway.

\section{Background}

Intracellular calcium, a secondary messenger, plays a key role in various physiological processes. Multiple studies have shown that extracellular calcium can act as a first messenger through the calcium-sensing receptor (CaSR) in various cells [1]. The CaSR belongs to the $C$ family of $G$ protein coupled receptors which was first cloned from bovine parathyroid gland by Brown et al [2]. The CaSR is important in maintaining and regulating mineral ion homeostasis. Increasing evidence has indicated that CaSR was functionally expressed in the cardiovascular system. Wang et al showed that CaSR was expressed in cardiac tissues and cardiomyocytes, and the activity of CaSR could be regulated by extracellular calcium and spermine [3]. $\mathrm{CaSR}$ is also expressed in vascular smooth muscle cells (SMCs). Wonneberger et al [4] and Ohanian et al [5]

\footnotetext{
* Correspondence: xucq45@126.com

+ Contributed equally

${ }^{2}$ Department of Pathophysiology, Harbin Medical University, Harbin 150086 PR China

Full list of author information is available at the end of the article
}

demonstrated that CaSR was involved in the regulation of myogenic tone in the gerbil spiral modiolar artery and in rat subcutaneous arteries. Recent study reported that stimulation of CaSR led to up-regulation of VSMC proliferation, and CaSR-mediated PLC activation was important for VSMC survival [6].

Whether the CaSR is expressed in pulmonary artery smooth muscle cells (PASMCs) and its function in PASMCs are unknown. There is marked difference between systemic and pulmonary circulation in physiological and pathophysiological conditions. For example, coronary artery is relaxed but pulmonary artery is contracted under hypoxic condition. Pulmonary vasoconstriction and PASMC proliferation may contribute to hypoxic pulmonary hypertension. Thus, the present study investigated the expression of CaSR in PAMSCs as well as the effect of CaSR activation on pulmonary artery tension in order to provide an experimental basis for the mechanism of pulmonary hypertension involved by CaSR.

\section{Biomed Central}




\section{Methods}

\section{Cell preparation and culture}

Primary cultures of PASMCs were prepared as previously described [7-9]. Briefly, PASMCs were obtained from Wistar rat PAs. The isolated distal arterial rings were incubated in Hanks balanced salt solution containing $1.5 \mathrm{mg} / \mathrm{ml}$ of collagenase II (Sigma, USA) for $20 \mathrm{~min}$. After incubation, the connective tissue and a thin layer of the adventitia were carefully stripped off with fine forceps, and the endothelium was removed by gently scratching the intimal surface with a surgical blade. The remaining smooth muscles were then digested with $1.0 \mathrm{mg} / \mathrm{ml}$ of collagenase II for $120 \mathrm{~min}$ at $37^{\circ} \mathrm{C}$. The cells were cultured in DMEM supplemented with $20 \%$ FBS, penicillin (100 units/ml), streptomycin (100 units/ $\mathrm{ml}$ ), and cultured in a humidified incubator with $5 \% \mathrm{CO}_{2}$ for $3-5 \mathrm{~d}$ at $37^{\circ} \mathrm{C}$. The cells with typical hill-and-valley morphology, were prepared for experiments. Passage 3-8 cells at $80 \%$ confluence were used in all reported experiments [10]. This protocol was approved by Harbin Medical University (Harbin 150086, China).

\section{RT-PCR}

Total RNA from PASMCs was extracted according to the Trizol reagent (Invitrogen, USA) protocol and redissolved in $20 \mu \mathrm{l}$ of DEPC water before being stored at $-70^{\circ} \mathrm{C}$. RNA was spectrophotometrically quantified by measuring the optical density of samples at a wavelength of 260-280 nm. The nucleotide sequences of the primers used (TakaRa Co, Ltd.) were as follows: (1) CaSR: sense 5'-ttcggcatcagctttgtg-3', antisense 5'-tgaagatgatttcgtcttcc3'; (2) GAPDH: sense 5'-ctcaactacatggtctacatg -3', antisense 5'-tggcatggactgtggtcatgag-3', yielding predicted products of 234 and $420 \mathrm{bp}$, respectively. RT-PCR was performed according to the RT-PCR kit (Promega, USA) protocol. Cycling conditions were as follows: 35 cycles of denaturation at $94^{\circ} \mathrm{C}$ for $20 \mathrm{~s}$, annealing at $55^{\circ} \mathrm{C}$ for $40 \mathrm{~s}$, and polymerization at $72^{\circ} \mathrm{C}$ for $40 \mathrm{~s}$. Aliquots $(5 \mu \mathrm{L})$ of PCR reactions were electrophoresed through ethidium bromide-stained $1.2 \%$ agarose gels and visualized with ethidium bromide. Identity was confirmed by sequencing (Shanghai Sangon Biological Engineering Technology \& Services Co.Ltd.) [11].

\section{Western blotting analysis}

Total proteins of the PASMCs were prepared as previously described [12]. Briefly, cells were washed three times with ice-cold phosphate-buffered saline (PBS) and then incubated in cool protein lysate containing the protease inhibitor phenylmethyl sulfonyl fluoride (PMSF) for $20 \mathrm{~min}$. The cells were centrifuged at $14000 \mathrm{~g}$ for $15 \mathrm{~min}$ at $4{ }^{\circ} \mathrm{C}$ to remove nuclei and undisrupted cells. The protein concentration of the supernatant was determined using the Bradford protein assay with BSA as a standard. Pulmonary artery tissues and rat cardiac tissue were homogenized with a polytron homogenizer in cool protein lysate containing the protease inhibitor PMSF for $1 \mathrm{~h}$. Protein samples of $40 \mu \mathrm{g}$ from different experimental groups were separated by $10 \%$ SDS-PAGE and transferred to nitrocellulose membranes by electroblotting (300 $\mathrm{mA}$ for $2 \mathrm{~h}$ ). The membranes were blocked in TBST (137 mM NaCl, $20 \mathrm{mM}$ Tris (pH 7.6), and 0.1\% (v/v) Tween 20$)$ containing $5 \%(\mathrm{w} / \mathrm{v})$ skimmed milk at $37^{\circ} \mathrm{C}$ for $1 \mathrm{~h}$. The membranes were then incubated overnight at $4{ }^{\circ} \mathrm{C}$ with antibodies against $\mathrm{CaSR}$ and anti- $\beta$ actin (1:500). The membrane of the negative controls was incubated with the antigen-antibody complex. Primary antibodies (a rabbit polyclonal antibody) and antigenic peptides were obtained from Santa Cruz Biotechnology Inc. (Santa Cruz, CA). The membranes were incubated with secondary antibody AP-IgG(Promega, USA) diluted 1:5000 in TBST for $1 \mathrm{~h}$ at room temperature. Antibodyantigen complexes were detected using Western Blue (Promega, USA).

\section{Immunofluorescence study}

The isolated PASMCs were placed onto coverslips, which were covered in 24-well culture plates with polylysine. After cultured for $72 \mathrm{~h}$ at $37^{\circ} \mathrm{C}$, the PASMCs were washed with PBS, fixed with $4 \%$ formaldehyde in PBS for $10 \mathrm{~min}$, and blocked in 1\% BSA for $30 \mathrm{~min}$. The cells were incubated with antibody against CaSR (1:100) or the antigenantibody complex (Santa Cruz, CA) overnight at $4{ }^{\circ} \mathrm{C}$. Then, the cells were incubated with secondary IgG (Santa Cruz, CA) (1:1000) conjugated with fluorescein isothiocyanate (FITC), for $1 \mathrm{~h}$ at $37^{\circ} \mathrm{C}$ and washed in PBS and $0.1 \%$ Tween 20. DAPI (4,6-diamidino-2-phenylindole; final concentration of $6 \mu \mathrm{g} / \mathrm{ml}$, Sigma-Aldrich, USA) was included to label nuclei. Fluorescence images were collected with a fluorescence microscope (Leica, Germany).

The separated pulmonary arteries were submerged in freezing embedding medium (2.5\% polyvinyl alcohol) and placed in liquid nitrogen, sliced by a freezing microtome, fixed with acetone for $5 \mathrm{~min}$, washed with PBS for $10 \mathrm{~min}$, and blocked in 1\% BSA for $30 \mathrm{~min}$. The pulmonary arteries were stained by immunofluorescence similarly to the isolated PASMCs as described above.

\section{Fluo-3/AM measurements of $\left[\mathrm{Ca}^{2+}\right]_{\mathrm{i}}$}

The isolated PASMCs were placed onto coverslips, which were covered in 6-well culture plates with polylysine. After $72 \mathrm{~h}$ at $37^{\circ} \mathrm{C}$, the PASMCs were washed with PBS and were then incubated with $5 \mu \mathrm{M}$ Fluo-3/AM for $30 \mathrm{~min}$ at $37^{\circ} \mathrm{C}$ in the dark. The cells were rinsed three times with Tyrode's solution to remove the remaining dye, and they were further incubated in Tyrode's 
solution or $\mathrm{Ca}^{2+}$-free Tyrode's solution. During the experiment, FI (fluorescence intensity) of fluo-3 in PASMCs was recorded using a laser-scanning confocal microscope (Olympus, Japan) with excitation at $488 \mathrm{~nm}$ and emission at $530 \mathrm{~nm}$.

Following a 60s baseline recording in $1.8 \mathrm{mM} \mathrm{CaCl}_{2}$, $\mathrm{CaCl}_{2}$ concentration in the medium was increased gradually from 2.5 to $12.5 \mathrm{mM}$, and intracellular fluo-3 fluorescence measurements continued for $300 \mathrm{~s}$. In another groups, cells were exposed to $\mathrm{Ca}^{2+}(10 \mathrm{mM})$ and $\mathrm{Gd}^{3+}$ $(300 \mu \mathrm{M})$ and then recorded for $120 \mathrm{~s}$ at $3 \mathrm{~s}$ intervals. In some experiments, the PASMCs preincubated with specific inhibitor, $\mathrm{NiCl}_{2}\left(0.1 \mathrm{mM}\right.$, inhibitor of $\mathrm{Na}^{+}-\mathrm{Ca}^{2+}$ exchanger) [12,13], $\mathrm{CdCl}_{2}$ (0.02 $\mathrm{mM}$, inhibitor of L-type calcium channel) [12,13], NPS2390 $(10 \mu \mathrm{M}$, antagonist of CaSR) $[14,15]$, U73122 (10 $\mu \mathrm{M}$, PLC-specific inhibitor $)$ $[16,17]$, U73343 $(10 \mu \mathrm{M}, \mathrm{U} 73122$ inactive analogue) [17], thapsigargin $(10 \mu \mathrm{M}$, blocker of sarcoplasmic reticulum calcium-ATPase) $[18,19]$, caffeine $(10 \mathrm{mM}$, depleted agent of the ryanodine receptor-operated $\mathrm{Ca}^{2+}$ store) [18] for $30 \mathrm{~min}$ and 2 - $\mathrm{APB}\left(75 \mu \mathrm{M}, \mathrm{IP}_{3}\right.$ receptor antagonist) [20] for 20 min before $\mathrm{Ca}^{2+}(10 \mathrm{mM})$ and $\mathrm{Gd}^{3+}(300 \mu \mathrm{M})$ challenge. Image analysis was performed off-line using Fluoview-FV300 (Olympus, Japan) to select cell regions from which FI was extracted, and further analysis was conducted with Excel (Microsoft) and Origin Version 7.5 software (OriginLab Corporation). $\left[\mathrm{Ca}^{2+}\right]_{\mathrm{i}}$ changes were expressed as fluorescence intensity representing FI and normalized to initial fluorescence intensity $\left(\mathrm{FI}_{0}\right)$ [20].

\section{Tension studies of pulmonary artery rings}

Adult male Wistar rats (200-250 g) were provided by the Experimental Animal Center of Harbin Medical University, which is fully accredited by the Institutional Animal Care and Use Committee. The experiment was carried out according to the published protocols [21-23]. Rats were anesthetized with pentobarbital sodium $(50 \mathrm{mg} / \mathrm{kg})$. The chest was opened, and then both the heart and lung were removed and immediately placed in cold Krebs solution (in $\mathrm{mM}: \mathrm{NaCl} 118$, $\mathrm{KCl}$ 4.7, $\mathrm{CaCl}_{2} 2.5, \mathrm{MgSO}_{4}$ 0.57, $\mathrm{KH}_{2} \mathrm{PO}_{4} 1.2, \mathrm{NaHCO}_{3}$ 20, EDTA- $\mathrm{Na}_{2} 0.02$ and Glucose 10, pH 7.4). The pulmonary arteries (PAs) were dissected out, cleaned of connective tissue and cut into rings under a dissecting microscope. Microdissected distal PAs were cut into rings of approximately 0.5 to $1.5 \mathrm{~mm}$ in diameter and examined for isometric contractile responses as described [21-23]. The rings were attached to tensionmeasuring devices by tungsten wire hooks. Pulmonary arterial rings were treated with $\mathrm{CaCl}_{2}$ or $\mathrm{GdCl}_{3}$ (Sigma-Aldrich, USA) at various concentrations, and the ring tensions were recorded. After $\mathrm{CaCl}_{2}$ or $\mathrm{GdCl}_{3}$ was washed off, all vessels relaxed to baseline level.
Afterwards, the vessels were incubated with $10 \mathrm{mM}$ $\mathrm{NiCl}_{2}$ (inhibitor of $\mathrm{Na}^{+}-\mathrm{Ca}^{2+}$ exchanger), $0.2 \mathrm{mM}$ $\mathrm{CdCl}_{2}$ (inhibitor of L-type calcium channel), $50 \mu \mathrm{M}$ thapsigargin (Sigma-Aldrich, USA. blocker of sarcoplasmic reticulum calcium-ATPase), $10 \mu \mathrm{M}$ NPS2390 (Sigma-Aldrich, USA. antagonist of CaSR), $10 \mathrm{mM}$ caffeine (Sigma-Aldrich, USA, depleted agent of the ryanodine receptor-operated $\mathrm{Ca}^{2+}$ store), $50 \mu \mathrm{M}$ U73122 (Sigma-Aldrich, USA. PLC-specific inhibitor), $50 \mu \mathrm{M}$ U73343 (Sigma-Aldrich, USA. U73122 inactive analogue), and $150 \mu \mathrm{M}$ 2-APB (Sigma-Aldrich, USA. IP 3 receptor antagonist) for $30 \mathrm{~min}$. They were then exposed to $\mathrm{CaCl}_{2}$ or $\mathrm{GdCl}_{3}$ at various concentrations again, and finally the ring tensions were recorded. Tension data were relayed from the pressure transducers to a signal amplifier. Data were acquired and analyzed with CODAS software (DataQ Instruments, Inc.).

\section{Statistical analysis}

Statistical analysis was carried out with SAS version 9.1. A two-sided $\mathrm{P}<0.05$ was considered significant. Continuous variables were expressed as mean \pm standard deviation $\bar{X} \pm S D$. The statistical differences betweengroup were tested with repeated measurement ANOVA.

\section{Results}

\section{CaSR mRNA expression in rat PASMCs}

A cDNA fragment of 234 bp corresponding to the selected CaSR mRNA sequence was detected in PASMCs (Figure 1A). In the absence of reverse transcriptase, no PCR-amplified fragments could be detected, indicating the tested RNA samples were free of genomic DNA contamination. Sequencing results were as follows: ttcggcatcagctttgtgctctgtatctcgtgcatcttggtgaagaccaatcgcgtcctcctggtatttgaagccaagatacccaccagcttc caccggaagtggtgggggctcaacct gcagttcctgctggttttcctctgcaccttcatgcagatcctcatctgcatcatctggctctacacggcgccccctc tagcaccgcaaccatgagctggaagacgaaatcatcttca. The sequence shared $100 \%$ identity with the rat CaSR sequence (GenBank/EMBL accession ).

\section{Protein expression of CaSR in rat PASMCs and PAs}

Western blotting with monoclonal CaSR-specific antibody revealed signal of apparent molecular seize of $130 \mathrm{kD}$ in the protein lysates of cultured PASMCs and rat pulmonary artery, consistent with the reported band in cardiac tissue, and there were no bands in the specific antigenic peptides groups (Figure 1B). Immunofluorescence staining showed that CaSR proteins were present in cytoplasm and membrane of the PASMCs (Figure 1C), as well as in rat PAs (Figure 1D). The specific antigenic peptide completely abolished CaSR immunostaining (Figure $1 \mathrm{C}$ and $1 \mathrm{D}$ ). 
A

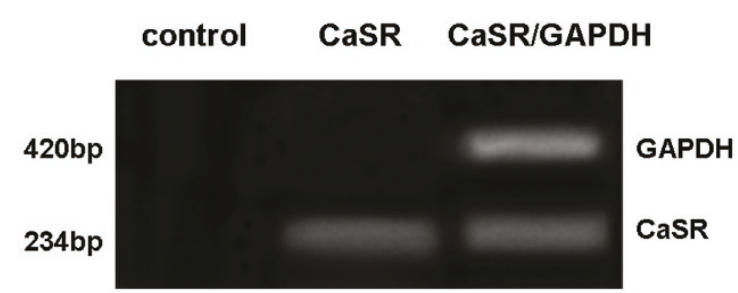

B

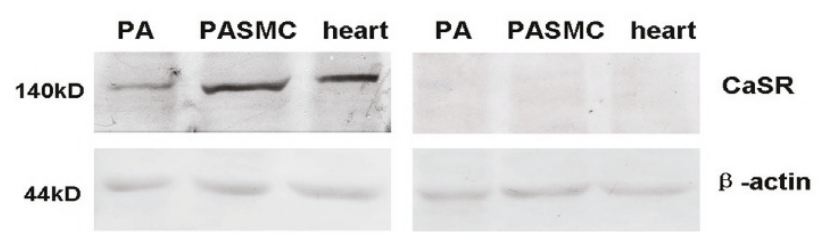

c

Anti-CaSR Ig

Antigenic peptide
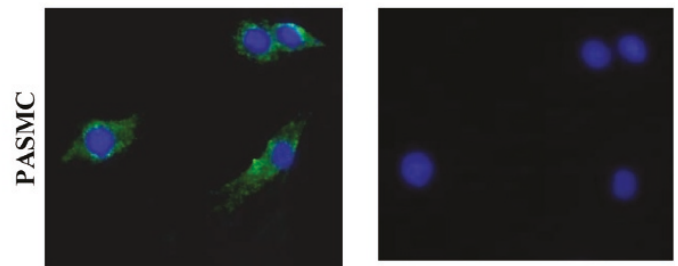

D
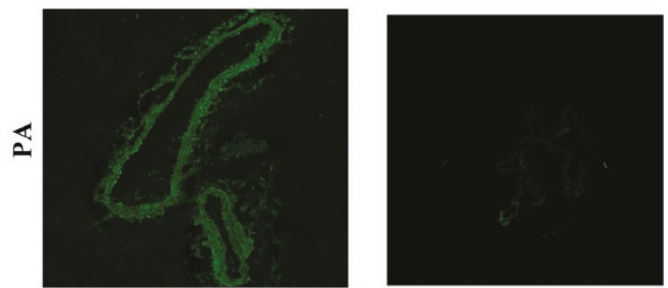

Figure 1 The calcium sensing receptor (CaSR) is expressed in pulmonary artery smooth muscle cells (PASMCs) and homogenates of pulmonary arteries (PAs). A. Detection of CaSR mRNA by RT-PCR in rat PASMCs in the absence or presence of reverse transcriptase and GAPDH. B. Detection of CaSR protein by western blotting in rat cultured PASMCs and PAs. Positive and negative control from rat cardiac tissue (left) and the specific antigenic peptides (right) are also shown. C. Immunofluorescence detection of CaSR in rat PASMCs in the presence of antiCaSR Ig conjugated with FITC (left) and in the presence of specific antigenic peptides and anti-CaSR Ig (right), (magnification: 400 ×). D. Immunofluorescence detection of CaSR in rat PAs in the presence of anti-CaSR Ig conjugated with FITC (left) and in the presence of specific antigenic peptides and anti-CaSR Ig (right) (magnification: $200 \times$ ), bar $=50 \mu \mathrm{M}$.

Increase in $\left[\mathrm{Ca}^{2+}\right]_{0}$ stimulated an increase in $\left[\mathrm{Ca}^{2+}\right]_{\mathrm{i}}$ via CaSR An initial $\mathrm{FI} / \mathrm{FI}_{0}$ was regarded as 1.0. As shown in Fig. 2A $(\mathrm{n}=20)$, when $\left[\mathrm{Ca}^{2+}\right]_{\mathrm{o}}$ increased from 5 to $12.5 \mathrm{mM}$, FI of $\left[\mathrm{Ca}^{2+}\right]_{\mathrm{i}}$ was increased in a concentration-dependent manner. Moreover, we also found that $10 \mathrm{mM} \mathrm{Ca}^{2+}$ increased the FI of $\left[\mathrm{Ca}^{2+}\right]_{\mathrm{i}}$ to $1.297 \pm 0.150$ at $30 \mathrm{~s}, 1.357$ \pm 0.176 at $60 \mathrm{~s}, 1.402 \pm 0.183$ at $90 \mathrm{~s}$, and $1.419 \pm 0.176$ at $120 \mathrm{~s}$ in the absence of $\mathrm{NiCl}_{2}, \mathrm{CdCl}_{2}$ and NPS2390. The FI of $\left[\mathrm{Ca}^{2+}\right]_{\mathrm{i}}$ in both the $\mathrm{NiCl}_{2}+\mathrm{CdCl}_{2}+\mathrm{CaCl}_{2}$ group and the NPS2390 $+\mathrm{CaCl}_{2}$ group was decreased but higher than that in controls ( $p<0.01$ versus control), and the FI of $\left[\mathrm{Ca}^{2+}\right]_{\mathrm{i}}$ was decreased significantly in the $\mathrm{NiCl}_{2}+\mathrm{CdCl}_{2}+\mathrm{NPS} 2390+\mathrm{CaCl}_{2}$ group $(p<0.01$ versus $\mathrm{CaCl}_{2}$ group) (Figure $2 \mathrm{~B}, \mathrm{n}=20$ ).

CaSR activation-induced increase in $\left[\mathrm{Ca}^{2+}\right]_{\mathrm{i}}$ is dependent on intracellular $\mathrm{Ca}^{2+}$ store in PASMCs

Under normal conditions, the increase of intracellular $\mathrm{Ca}^{2}$ ${ }^{+}$is from extracellular $\mathrm{Ca}^{2+}$ entry and release of intracellular $\mathrm{Ca}^{2+}$ store. To verify that the change in $\left[\mathrm{Ca}^{2+}\right]_{\mathrm{i}}$ induced by activation of CaSR is dependent on the intracellular $\mathrm{Ca}^{2+}$ store, the PASMCs were incubated with $10 \mathrm{mM}$ caffeine and $10 \mu \mathrm{M}$ thapsigargin for $30 \mathrm{~min}$, then $10 \mathrm{mM}$ $\mathrm{CaCl}_{2}$ or $300 \mu \mathrm{M} \mathrm{GdCl}_{3}$ were added into the media. It was found that $\mathrm{Ca}^{2+} \mathrm{FI} / \mathrm{FI}_{0}$ was significantly reduced in the presence of caffeine and thapsigargin $(p<0.01$ versus $\mathrm{CaCl}_{2}$ or $\mathrm{GdCl}_{3}$ group) (Figure $3 \mathrm{~A}$ and $3 \mathrm{~B}, \mathrm{n}=20$ ).
CaSR activation induced an increase in $\left[\mathrm{Ca}^{2+}\right]_{i}$ in PASMCs via the $\mathrm{PLC}-\mathrm{IP}_{3}$ signal transduction pathway

Compared with the $10 \mathrm{mM} \mathrm{Ca}{ }^{2+}$ group, $\mathrm{FI} / \mathrm{FI}_{0}$ of $\left[\mathrm{Ca}^{2+}\right]_{\mathrm{i}}$ was decreased in the 2-APB and U73122 pretreated groups. However, U73343 had little effect on $\left[\mathrm{Ca}^{2+}\right]_{\mathrm{i}} \mathrm{FI} /$ $\mathrm{FI}_{0}$ (Figure 3A). The treatment with $300 \mu \mathrm{M} \mathrm{Gd}^{3+}$ also caused a similar response (Figure $3 \mathrm{~B}, \mathrm{n}=20$ ).

\section{Calcium-induced constriction of pulmonary artery rings}

An isometric tension of $0.3 \mathrm{~g}$ (passive force) was regarded as $100 \%$ (vehicle). We observed that an increase in the $\left[\mathrm{Ca}^{2+}\right.$ ]o from 0.5 to $2.5 \mathrm{mM}$ exerted no effect on tension of the pulmonary artery rings, while increases in $\left[\mathrm{Ca}^{2+}\right]$ o from 5 to $12.5 \mathrm{mM}$ increased vasoconstriction in a dose-dependent manner. In addition, the vasoconstriction was not completely eliminated by $\mathrm{NiCl}_{2}, \mathrm{CdCl}_{2}$, or NPS2390 (Figure $4, \mathrm{n}=8$ ), indicating that $\left[\mathrm{Ca}^{2+}\right]_{\mathrm{o}}$-induced vasoconstriction was at least partly mediated via activation of CaSR.

\section{CaSR activation-induced constriction of pulmonary artery} rings is dependent on intracellular $\mathrm{Ca}^{2+}$ store

We observed that preincubation with $10 \mathrm{mM}$ caffeine or $50 \mu \mathrm{M}$ thapsigargin for $30 \mathrm{~min}$ before $\mathrm{Ca}^{2+}$ and $\mathrm{Gd}^{3+}$ challenge attenuated the constriction of pulmonary artery rings significantly ( $p<0.01$ versus the $\mathrm{CaCl}_{2}$ or $\mathrm{GdCl}_{3}$ group) (Figure $5 \mathrm{~A}, \mathrm{~B} . \mathrm{n}=8$ ). 

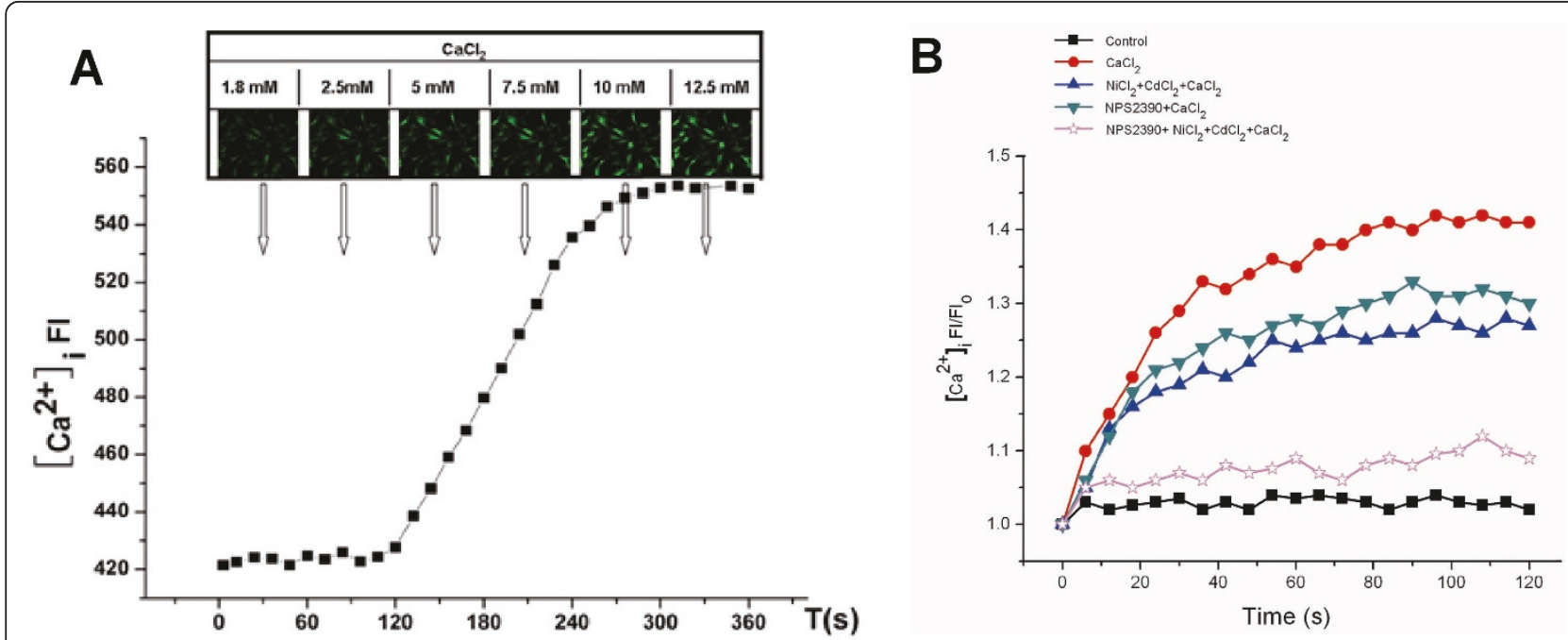

Figure 2 Effect of different extracellular calcium concentrations $\left(\left[\mathrm{Ca}^{2+}\right]_{0}\right)$, the CaSR antagonist (NPS2390), blocker of L-type calcium channels $\left(\mathrm{CdCl}_{2}\right)$, and inhibitor of $\mathrm{Na}^{+}-\mathrm{Ca}^{2+}$ exchanger $\left(\mathrm{NiCl}_{2}\right)$ on the intracellular calcium concentrations $\left(\left[\mathrm{Ca}^{2+}\right]_{i}\right)$ in the PAMSCs. A. $\left[\mathrm{Ca}^{2+}\right]_{0}$ from 5 to $12.5 \mathrm{mM}$ caused an increase fluorescent intensities of the $\left[\mathrm{Ca}^{2+}\right]_{\mathrm{i}}$ in a concentration dependent manner, then we chose 10 $\mathrm{mM}\left[\mathrm{Ca}^{2+}\right]$ for the futher experiments $(\mathrm{n}=20)$. B. The cells were exposed to $10 \mathrm{mM} \mathrm{Ca}{ }^{2+}$, and $\mathrm{Fl}$ of $\left[\mathrm{Ca}^{2+}\right]_{\mathrm{i}}$ was recorded for $120 \mathrm{~s}$. In some experiments, the cells were pre-exposed to $0.1 \mathrm{mM} \mathrm{NiCl}_{2}, 0.02 \mathrm{mM} \mathrm{CdCl}_{2}$, and $10 \mu \mathrm{M} \mathrm{NPS} 2390$ for 30 min before Ca ${ }^{2+}$ challenge.

CaSR activation-induced constriction of pulmonary artery rings via the $\mathrm{PLC}-\mathrm{IP}_{3}$ signal transduction pathway

Both $\mathrm{Ca}^{2+}$ and $\mathrm{Gd}^{3+}$ evoked increases in tension of pulmonary artery rings in a concentration-dependent manner. U73122 and 2-APB significantly inhibited the constriction of pulmonary artery rings. However, U73343 did not affect the vasoconstriction induced by $\mathrm{Ca}^{2+}$ and $\mathrm{Gd}^{3+}$ (Figure $5 \mathrm{~A}, \mathrm{~B} . \mathrm{n}=8$ ). Based on these findings, it was speculated that the $\mathrm{PLC}-\mathrm{IP}_{3}$ signal transduction pathway may be involved in CaSR-induced constriction.

\section{Discussion}

CaSRs are widely expressed in the vessel system, such as in the mesenteric, basilar, renal, coronary [24,25], spiral modiolar arteries [4], subcutaneous vessels [5] and in the aorta [26]. CaSRs are involved in regulation of vascular tension and cell proliferation in these vessels. Increasing evidence indicates that CaSRs play a potential role in vascular calcification and pathogenesis of atherosclerosis, arteriosclerosis and hypertension [27].

Whether the CaSR is expressed in the pulmonary artery has remained unclear. To confirm the existence of CaSRs and its functional expression in some tissues or cells, the following evidence would be necessary. Firstly, CaSR mRNA and protein would be present in the tissue or cells [4]. Secondly, an elevation of $\left[\mathrm{Ca}^{2+}\right]_{\mathrm{o}}$ would cause an increase of $\left[\mathrm{Ca}^{2+}\right]_{\mathrm{i}}$. Thirdly, the $\left[\mathrm{Ca}^{2+}\right]_{\mathrm{o}^{-}}$ induced increase in $\left[\mathrm{Ca}^{2+}\right]_{i}$ would be dependent on the
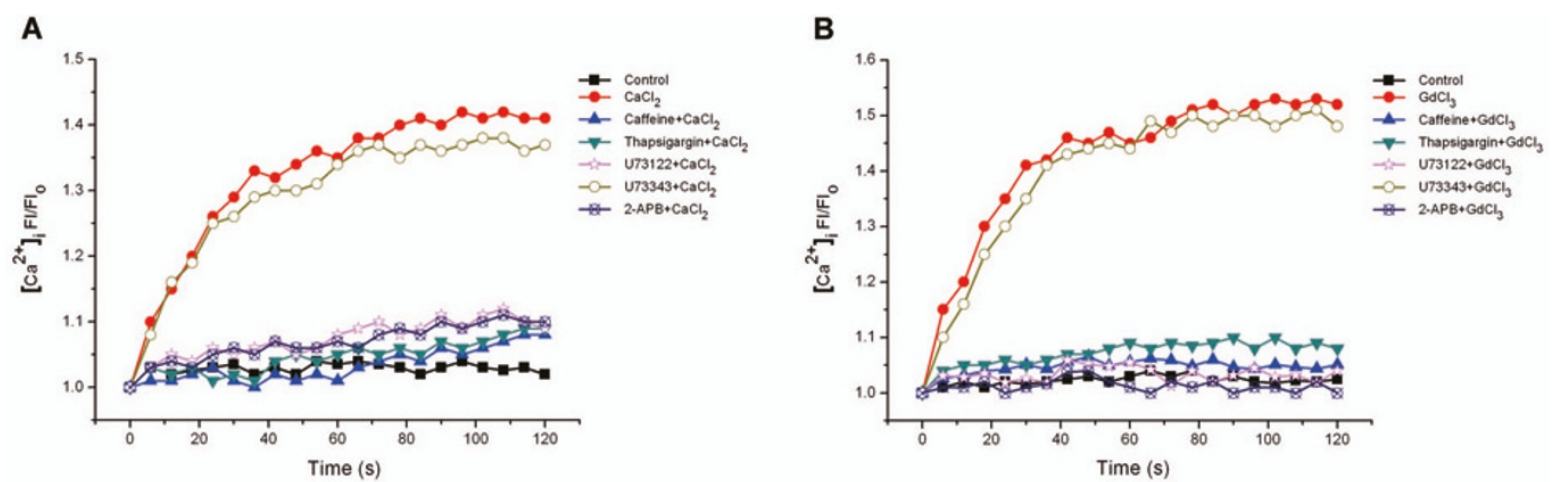

Figure 3 Effect of various inhibitors on the increase in $\left[\mathrm{Ca}^{2+}\right]_{i}$ induced by $10 \mathrm{mM}\left[\mathrm{Ca}^{2+}\right]_{0}$ or $300 \mu \mathrm{M} \mathrm{GdCl}{ }_{3}$ (CaSR agonists) in PASMCs. A.10 $\mathrm{mM}\left[\mathrm{Ca}^{2+}\right]_{0}$ caused an increased $\mathrm{Fl}$ of $\left[\mathrm{Ca}^{2+}\right]_{\mathrm{i}}(P<0.01$ versus control $)$, and the pretreatment with $10 \mu \mathrm{M}$ thapsigargin, $10 \mathrm{mM}$ caffeine, $10 \mu \mathrm{M}$ U73122, or $75 \mu \mathrm{M}$ 2-APB either decreased or abolish increase the $\mathrm{Fl}$ of $\left[\mathrm{Ca}^{2+}\right]_{\mathrm{i}}$ induced by $10 \mathrm{mM}\left[\mathrm{Ca}^{2+}\right]_{0}$, but $10 \mu \mathrm{M}$ U73343 had no significant effect on it $(n=20)$. B. The changes in patterns of $\left[\mathrm{Ca}^{2+}\right]_{i}$ induced by $300 \mu \mathrm{M} \mathrm{GdCl}$ and various inhibitors were the same as in $A$. 


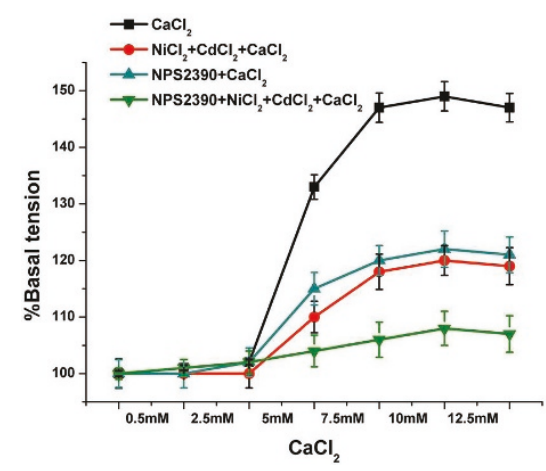

Figure 4 The effects of different treatments on the vascular tension of the pulmonary arteries with increased $\left[\mathrm{Ca}^{2+}\right]_{0} .\left[\mathrm{Ca}^{2+}\right]$ o from 5 to $12.5 \mathrm{mM}$ caused a vasoconstriction of the pulmonary arterys $(P<0.01$ versus vehicle, $\mathrm{n}=8)$. In the $\mathrm{NiCl}_{2}+\mathrm{CdCl}_{2}$ pretreated groups, the vasoconstriction of the pulmonary arterys was attenuated, but it was higher than in the vehicle $(P<0.01$ versus $\mathrm{CaCl}_{2}$ groups). In the NPS2390 pretreated groups, the vasoconstriction of the pulmonary arterys was also attenuated, but it was higher than in the vehicle ( $P<0.01$ versus $\mathrm{CaCl}_{2}$ groups). In the NPS2390 $+\mathrm{NiCl}_{2}+\mathrm{CdCl}_{2}$ treated groups, the vasoconstriction of the pulmonary artery was significantly attenuated.

release of $\mathrm{Ca}^{2+}$ from thapsigargi- and caffeine-sensitive intracellular stores and dependent on PLC-activation. Fourthly, the CaSR agonists- $\mathrm{Gd}^{3+}$ would cause the same response as an elevation of $\left[\mathrm{Ca}^{2+}\right]_{\mathrm{o}}$ would $[4,28,29]$.

In this study, comprehensive experiments were carried out, including RT-PCR with CaSR-specific primers, western blotting, and immunofluorescence staining. A cDNA fragment of $234 \mathrm{bp}$ was found in cultured PASMCs, indicating the presence of CaSR mRNA in rat PASMCs. Western blotting analysis showed that CaSR was clearly expressed in rat PASMCs as well as in whole PAs extracts. Heart tissues were used as positive control, and we detected the same size of band $(130 \mathrm{kDa})$ in the lysates of PAMSCs, PAs and heart. There were no bands in specific antigenic peptide groups. However, Ohanian et al. reported that immunoblotting of rat subcutaneous artery homogenates with monoclonal CaSR antibody revealed a single immunoreactive band at $159 \mathrm{kDa}$. This antibody also detected another two bands at 145 and $168 \mathrm{kDa}$ in rat kidney homogenate. CaSR protein is present in human aortic smooth muscle cells, and lysate produces a band $160 \mathrm{kDa}$ [30]. It is generally agreed that bands of 130-170 kDa represent a mature, fully glycosylated form of the CaSR [3,23]. Usually, the band size of CaSR detected by western blotting varies considerably depending on the tissue and cell type, cellular fraction analyzed (membrane or cytosolic), and degree of posttranslational modification (glycosylation) of the CaSR protein [31]. Therefore, the CaSR proteins we detected in rat cultured PASMCs and whole pulmonary artery extract may belong to the mature form of CaSR. Immunofluorescence staining showed that CaSR proteins were observed in vessel walls of PAs and were located in the cytoplasm and plasmalemma of the PASMCs, as shown in other cell types $[32,33]$. Based on these data, we confirmed the expression of CaSR in PASMCs at the mRNA and protein levels.

To confirm that $\left[\mathrm{Ca}^{2+}\right]_{\mathrm{o}}$ causes an elevation of $\left[\mathrm{Ca}^{2+}\right]_{\mathrm{i}}$ mediated by CaSR, Fluo-3/AM was used to measure $\left[\mathrm{Ca}^{2}\right.$ $\left.{ }^{+}\right]_{\mathrm{i}}$. The EC50 for $\mathrm{Ca}^{2+}$ activation of CaSR is $3-4 \mathrm{mM}$ [34]. In the present study, it was found that a $\left[\mathrm{Ca}^{2+}\right]_{\mathrm{o}}$ from 1.8 to $2.5 \mathrm{mM}$ had no effect on $\left[\mathrm{Ca}^{2+}\right]_{\mathrm{i}}$, and a $\left[\mathrm{Ca}^{2+}\right]$ o from 5 to $12.5 \mathrm{mM}$ induced an elevation of $\left[\mathrm{Ca}^{2+}\right]_{\mathrm{i}}$ in a concentration-dependent manner. This means that in PASMCs, the increase of $\left[\mathrm{Ca}^{2+}\right]_{\mathrm{o}}$ can cause an elevation of $\left[\mathrm{Ca}^{2+}\right]_{\mathrm{i}}$. Additionally, in the presence of $\mathrm{NiCl}_{2}$ and $\mathrm{CdCl}_{2}$, the $\mathrm{FI}$ of $\left[\mathrm{Ca}^{2+}\right]_{\mathrm{i}}$ has decreased, it is still higher than control group. Furthermore, NPS2390 also decreased the FI of $\left[\mathrm{Ca}^{2+}\right]_{\mathrm{i}}$. However, the elevation of
A

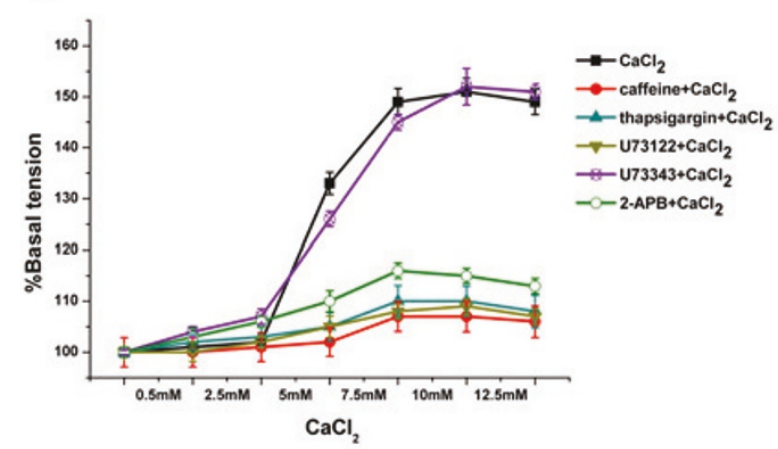

B

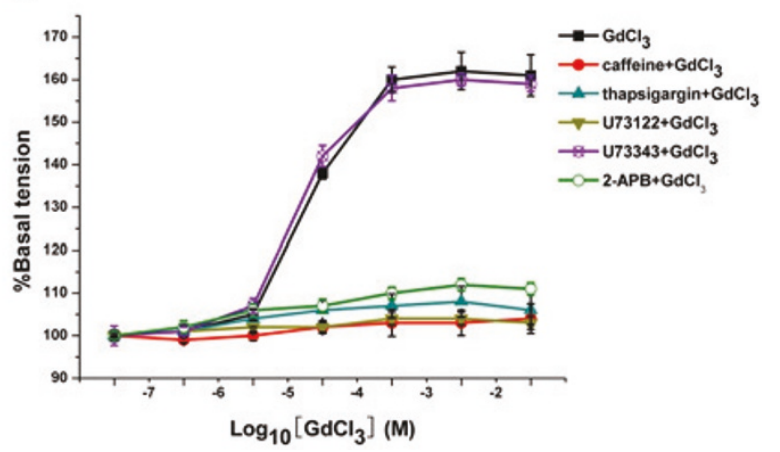

Figure 5 Effect of various inhibitors on the $\left[\mathrm{Ca}^{2+}\right]_{\mathrm{o}}$ or the $\left[\mathrm{Gd}^{3+}\right]_{\mathrm{o}}$-induced vasoconstriction. $\mathrm{A}$. An increase in $\left[\mathrm{Ca}^{2+}\right]_{0}$ from 5 to $12.5 \mathrm{mM}$ caused a vasoconstriction of the pulmonary arteries ( $P<0.01$ versus vehicle). In the $10 \mathrm{mM}$ caffeine, $50 \mu \mathrm{M}$ thapsigargin, $50 \mu \mathrm{M}$ U73122 or $150 \mu \mathrm{M}$ 2-APB pretreated groups, the vasoconstriction of the pulmonary arteryies was attenuated, but $50 \mu \mathrm{M}$ U73343 had no effect on the vasoconstrictions $(n=8)$. B. $\left[\mathrm{Gd}^{3+}\right]_{0}$ from $10^{-6}$ to $10^{-2} \mathrm{M}$ caused similar changes. 
$\left[\mathrm{Ca}^{2+}\right]_{\mathrm{i}}$ induced by $10 \mathrm{mM} \mathrm{CaCl}$ was nearly abolished in the $\mathrm{NiCl}_{2}+\mathrm{CdCl}_{2}+\mathrm{NPS} 2390$ group. These results indicated that CaSRs were involved in the elevation of $\left[\mathrm{Ca}^{2+}\right]_{\mathrm{i}}$ induced by an increased $\left[\mathrm{Ca}^{2+}\right]_{\mathrm{o}}$, or that CaSRs at least played a partial role in this process.

In the present study, we found that the pretreatment with caffeine and thapsigargin for $30 \mathrm{~min}$ prevented a significant increase of $\left[\mathrm{Ca}^{2+}\right]_{\mathrm{i}}$ induced by elevated $\left[\mathrm{Ca}^{2+}\right]_{\mathrm{o}}$ or $\left[\mathrm{Gd}^{3+}\right]_{\mathrm{o}}$ in PASMCs. It is well known that caffeine is a depletion agent of the ryanodine receptor operated at the $\mathrm{Ca}^{2+}$ store and that thapsigargin is a blocker of sarcoplasmic reticulum calcium ATPase. This suggests that increased $\left[\mathrm{Ca}^{2+}\right]_{\mathrm{i}}$ induced by CaSR activation is from thapsigargin and caffeine sensitive intracellular $\mathrm{Ca}^{2+}$ stores.

Wang et al reported that elevated $\left[\mathrm{Ca}^{2+}\right]_{\mathrm{o}}, \mathrm{Gd}^{3+}$ or spermine can cause $\mathrm{Ca}^{2+}$ release from the sarcoplasmic reticulum of rat myocardium via the $\mathrm{G}$ protein-PLC-IP 3 signal transduction pathway [3]. In our experiments, U73122, U73343 and 2-APB were used to reveal the pathway by which CaSR activation causes an increase in $\left[\mathrm{Ca}^{2+}\right]_{\mathrm{i}}$ in PASMCs. The results showed that, compared with the $10 \mathrm{mM} \mathrm{Ca}{ }^{2+}$ group, the $\mathrm{FI} / \mathrm{FI}_{0}$ of $\left[\mathrm{Ca}^{2+}\right]_{\mathrm{i}}$ was markedly decreased in the 2-APB and U73122 pretreated groups. However, preincubation with U73343 did not alter $10 \mathrm{mM}\left[\mathrm{Ca}^{2+}\right]_{\mathrm{o}}$-induced elevation of $\left[\mathrm{Ca}^{2+}\right]_{\mathrm{i}}$. Pretreatment with $300 \mu \mathrm{M} \mathrm{Gd}{ }^{3+}$ induced responses similar to those observed in $\mathrm{Ca}^{2+}$-treated cultures. These results suggested that activation of CaSR induced the increase in $\left[\mathrm{Ca}^{2+}\right]_{\mathrm{i}}$ in PASMCs through the $\mathrm{PLC} \mathrm{IP}_{3}$ signal transduction pathway.

As we have known, the intracellular $\mathrm{Ca}^{2+}$, as an excitation contraction coupling factor, is involved in regulating myocardial contraction and angiotasis. To demonstrate the functional expression of CaSR in PAs, evidence showing that CaSR activation is related to PA tension change needs to be provided. Therefore, we observed the effects of the CaSR agonist, antagonist and other calcium signalrelated factors on PAs tension. The results showed that vasoconstriction appeared in a concentration-dependent manner in PAs when $\left[\mathrm{Ca}^{2+}\right]_{\mathrm{o}}$ was increased from $5 \mathrm{mM}$ to $12.5 \mathrm{mM}$, and $\mathrm{Gd}^{3+}$ also induced a similar response. In addition, the vasoconstriction was not reversed by an inhibitor of the $\mathrm{Na}^{+}-\mathrm{Ca}^{2+}$ exchanger and L-type $\mathrm{Ca}^{2+}$ channels, antagonist of CaSR. These findings suggest that an increased $\left[\mathrm{Ca}^{2+}\right]_{\mathrm{o}}$ or $\left[\mathrm{Gd}^{3+}\right]_{\mathrm{o}}$ evoked vasoconstriction at least in part by the CaSR. In subcutaneous artery a biphasic response was observed. That is increasing $\left[\mathrm{Ca}^{2+}\right]$ o from 0.5 to $2 \mathrm{mM}$ induced a small vasoconstriction followed by progressive vasodilation from 3 to $10 \mathrm{mM}$ [5]. However, elevation of $\left[\mathrm{Ca}^{2+}\right]_{\mathrm{o}}$ caused a biphasic vasoconstriction in the spiral modiolar artery [4].

The signal transduction mechanism linked to the CaSR is known to involve the release of $\mathrm{Ca}^{2+}$ from cytosolic stores [35]. Therefore, the PAs were preincubated in caffeine or thapsigargin. We found that caffeine and thapsigargin induced a significant attenuation of the vasoconstriction induced by $\left[\mathrm{Ca}^{2+}\right]_{\mathrm{o}}$ or $\left[\mathrm{Gd}^{3+}\right]_{\mathrm{o}}$, suggesting that $\left[\mathrm{Ca}^{2+}\right]_{\mathrm{o}}$ or $\left[\mathrm{Gd}^{3+}\right]_{\mathrm{o}}$ induced constriction of PAs related to the $\mathrm{Ca}^{2+}$ release from thapsigargin and caffeine sensitive intracellular stores.

In the experiment with pulmonary artery rings, we also found that the increases in $\left[\mathrm{Ca}^{2+}\right]_{\mathrm{o}}$ or $\left[\mathrm{Gd}^{3+}\right]_{0}$ induced PA vasoconstriction were significantly inhibited by U73122 and 2-APB, but not U73343. Thus, the increases in PAs tension induced by $\mathrm{Ca}^{2+}$ and $\mathrm{Gd}^{3+}$ are linked to the PLC-IP 3 signaling pathway.

\section{Conclusions}

We have demonstrated that functional expression of CaSRs exists in rat PAs and PAMSCs, and that CaSR activation is involved in $\left[\mathrm{Ca}^{2+}\right]_{\mathrm{i}}$ increase and vasoconstriction through the G-PLC-IP ${ }_{3}$ signal transduction pathway. Pulmonary artery constriction contributes to pulmonary hypertension, so it is expected that CaSR activation could be involved in the development of pulmonary hypertension.

\section{Acknowledgements}

This research is supported by the National Natural Science Foundation of China (No.30871012, No.30700288, No.81070123), the Special Scientific Research Fund for Doctor Discipline of University (No. 20070226012) and the graduate innovative research projects in Heilongjiang Province (YJSCX2009$223 \mathrm{HLJ})$.

\section{Author details}

'Department of Pathophysiology, Qiqihar Medical University, Qiqihar 161006, PR China. ${ }^{2}$ Department of Pathophysiology, Harbin Medical University, Harbin 150086, PR China. ${ }^{3}$ Department of Pharmacology, Harbin Medical University, Harbin 150086, PR China. ${ }^{4}$ Bio-pharmaceutical Key Laboratory of Heilongjiang Province, Harbin 150086, PR China. ${ }^{5}$ The second affiliated hospital of Harbin Medical University, Harbin 150086, PR China. ${ }^{6}$ Department of Biology, Lakehead University, Thunder Bay, Ont., P7B5E1, Canada.

\section{Authors' contributions}

All authors participated in the design, interpretation of the studies and analysis of the data and review of the manuscript. B-FY, L-YW, RW and C-QX conducted the experiments. C-QX supplied critical reagents. G-WL, Q-SW wrote the manuscript. G-DY and W-hZ finished necessary language corrections to this manuscript. G-WL, Q-sW, J-HH and W-JX are equally contributed.

\section{Competing interests}

The authors declare that they have no competing interests.

Received: 2 August 2010 Accepted: 11 February 2011

Published: 11 February 2011

\section{References}

1. Tfelt-Hansen J, Brown EM: The calcium-sensing receptor in normal physiology and pathophysiology: a review. Crit Rev Clin Lab Sci 2005, 42:35-70.

2. Brown EM, Gamba G, Riccardi D, Lombardi M, Butters R, Kifor O, Sun A, Hediger MA, Lytton J, Hebert SC: Cloning and characterization of an extracellular $\mathrm{Ca}(2+)$-sensing receptor from bovine parathyroid. Nature 1993, 366:575-580 
3. Wang R, Xu CQ, Zhao WM, Zhang J, Cao K, Yang BF, Wu LY: Calcium and polyamine regulated calcium-sensing receptors in cardiac tissues. Eur $\mathrm{J}$ Biochem 2003, 270:2680-2688.

4. Wonneberger K, Scofield MA, Wangemann P: Evidence for a calciumsensing receptor in the vascular smooth muscle cells of the spiral modiolar artery. J Membr Biol 2000, 175:203-212.

5. Ohanian J, Gatfield KM, Ward DT, Ohanian V: Evidence for a functional calcium-sensing receptor that modulates myogenic tone in rat subcutaneous small arteries. Am J Physiol Heart Circ Physiol 2005 288:1756-1762

6. Molostvov G, Fletcher S, Bland R, Zehnder D: Extracellular calcium-sensing receptor mediated signalling is involved in human vascular smooth muscle cell proliferation and apoptosis. Cell Physiol Biochem 2008, 22:413-422.

7. Han WN, Tang XB, Wu H, Liu Y, Zhu DL: Role of ERK1/2 signaling pathways in 4-aminopyridine-induced rat pulmonary vasoconstriction. Eur J Pharmacol 2007, 569:138-144.

8. Wang ZG, Tang XB, Li YM, Leu CL, Guo L, Zheng XD, Zhu DL: 20Hydroxyeicosatetraenoic acid inhibits the apoptotic responses in pulmonary artery smooth muscle cells. Eur J Pharmacol 2008, 588:9-17.

9. Zhu DL, Medhora M, Campbell WB, Spitzbarth N, Baker JE, Jacobs ER: Chronic hypoxia activates lung 15-lipoxygenase, which catalyzes production of 15 -HETE and enhances constriction in neonatal rabbit pulmonary arteries. Circ Res 2003, 92:992-1000.

10. Li YM, Li Q, Wang ZG, Liang D, Liang SJ, Tang XB, Guo L, Zhang R, Zhu DL: 15-HETE suppresses $\mathrm{K}^{+}$channel activity and inhibits apoptosis in pulmonary artery smooth muscle cells. Apoptosis 2009, 14:42-51.

11. Wang LN, Wang C, Lin Y, Xi YH, Zhang WH, Zhao YJ, Li HZ, Tian Y, LV YJ, Yang BF, Xu CQ: Involvement of calcium-sensing receptor in cardiac hypertrophy-induced by angiotensin II through calcineurin pathway in cultured neonatal rat cardiomyocytes. Biochem Biophys Res Commun 2008, 369:584-589.

12. Sun YH, Liu MN, Li H, Shi S, Zhao YJ, Wang R, Xu CQ: Calcium-sensing receptor induces rat neonatal ventricular cardiomyocyte apoptosis. Biochem Biophys Res Commun 2006, 350:942-948.

13. Zhang WH, Fu SB, Lu FH, Wu B, Gong DM, Pan ZW, Lv YJ, Zhao YJ, Li QF, Wang R, Yang BF, Xu CQ: Involvement of calcium-sensing receptor in ischemia/reperfusion-induced apoptosis in rat cardiomyocytes. Biochem Biophys Res Commun 2006, 347:872-881

14. Kwak JO, Kwak J, Kim HW, Oh KJ, Kim YT, Jung SM, Cha SH: The extracellular calciumsensing receptor is expressed in mouse mesangial cells and modulates cell proliferation. EXP and MOL MED 2005, 37:457-465.

15. De Santis T, Casavola V, Reshkin SJ, Guerra L, Ambruosi B, Fiandanese N, Dalbies-Tran R, Goudet G, Dell'Aquila ME: The extracellular calcium-sensing receptor is expressed in the cumulusoocyte complex in mammals and modulates oocyte meiotic maturation. Reproduction 2009, 138:439-452.

16. Snetkov VA, Thomas GD, Teague B, Leach RM, Shaifta Y, Knock GA, Aaronson PI, Ward JP: Low Concentrations of Sphingosylphosphorylcholine Enhance Pulmonary Artery Vasoreactivity The Role of Protein Kinase $\mathrm{C}_{\beta}$ and $\mathrm{Ca}^{2+}$ Entry. Hypertension 2008, 51:239-245.

17. Ford CP, Stemkowski PL, Smith PA: Possible role of phosphatidylinositol 4,5 bisphosphate in luteinizing hormone releasing hormone-mediated M-current inhibition in bullfrog sympathetic neurons. Eur J Neurosci 2004, 20:2990-2998.

18. Lin MJ, Yang XR, Cao YN, Sham JS: Hydrogen peroxide-induced $\mathrm{Ca}^{2+}$ mobilization in pulmonary arterial smoot muscle cells. Am J Physiol Lung Cell Mol Physiol 2007, 292:1598-1608.

19. Ko EA, Park WS, Ko JH, Han J, Kim N, Earm YE: Endothelin-1 increases intracellular $\mathrm{Ca}^{2+}$ in rabbit pulmonary artery smooth muscle cells through phospholipase C. Am J Physiol Heart Circ Physiol 2005, 289:1551-1559.

20. Zheng XD, Li Q, Tang XB, Liang SJ, Chen LP, Zhang S, Wang ZG, Guo L, Zhang R, Zhu DL: Source of the elevation $\mathrm{Ca}^{2+}$ evoked by 15 -HETE in pulmonary arterial myocytes. Eur J Pharmacol 2008, 601:16-22.

21. Chu XJ, Tang XB, Guo L, Bao HX, Zhang S, Zhang JN, Zhu DL: Hypoxia suppresses $\mathrm{K}_{\mathrm{v}} 1.5$ channel expression through endogenous 15-HETE in rat pulmonary artery. Prostaglandins Other Lipid Mediat 2009, 88:42-50.

22. Kunichika N, Yu Y, Remillard CV, Platoshyn O, Zhang S, Yuan JX: Overexpression of TRPC1 enhances pulmonary vasoconstriction induced by capacitative $\mathrm{Ca}^{2+}$ entry. Am J Physiol Lung Cell Mol Physiol 2004, 287:962-969.

23. Yuan XJ, Goldman WF, Tod ML, Rubin LJ, Blaustein MP: Ionic currents in rat pulmonary and mesenteric arterial myocytes in primary culture and subculture. Am J Physiol 1993, 264:107-115.

24. Bukoski RD, Bian K, Wang Y, Mupanomunda M: Perivascular sensory nerve $\mathrm{Ca}^{2+}$ receptor and $\mathrm{Ca}^{2+}$-induced relaxation of isolated arteries. Hypertension 1997, 30:1431-1439.

25. Wang $Y$, Bukoski RD: Distribution of the perivascular nerve $\mathrm{Ca}^{2+}$ receptor in rat arteries. Br J Pharmacol 1998, 125:1397-1404.

26. Smajilovic S, Hansen JL, Christoffersen TE, Lewin E, Sheikh SP, Terwilliger EF, Brown EM, Haunso S, Tfelt-Hansen J: Extracellular calcium sensing in rat aortic vascular smooth muscle cells. Biochem Biophys Res Commun 2006, 348:1215-1223.

27. Molostvov G, Bland R, Zehnder D: Expression and role of the calciumsensing receptor in the blood vessel wall. Curr Pharm Biotechnol 2009, 10:282-288.

28. Ray JM, Squires PE, Curtis SB, Meloche MR, Buchan AM: Expression of the calcium-sensing receptor on human antral gastrin cells in culture. $J$ Clin Invest 1997, 99:2328-2333.

29. Sanders $J$, Chattopadhyay N, Kifor O, Yamaguchi T, Butters RR, Brown EM: Extracellular calcium-sensing receptor expression and its potential role in regulating parathyroid hormone-related peptide secretion in human breast cancer cell lines. Endocrinology 2000, 141:4357-4364

30. Molostvov G, James S, Fletcher S, Bennett J, Lehnert H, Bland R, Zehnder D: Extracellular calcium-sensing receptor is functionally expressed in human artery. Am J Physiol Renal Physiol 2007, 293:946-95.

31. Ziegelstein RC, Xiong Y, He C, Hu Q: Expression of a functional extracellular calcium-sensing receptor in human aortic endothelial cells. Biochem Biophys Res Commun 2006, 342:153-163.

32. Brown EM, MacLeod RL: Extracellular calcium sensing and extracellular calcium signalling. Physiol Rev 2001, 81:239-297.

33. Tu CL, Chang W, Bikle DD: The role of the calcium sensing receptor in regulating intra-cellular calcium handling in human epidermal keratinocytes. J Invest Dermatol 2007, 127:1074-1083.

34. Zhang $\mathrm{WH}, \mathrm{Xu} \mathrm{CQ}$ : Calcium sensing receptor and heart diseases. Pathophysiology 2009, 16:317-323.

35. Treiman M, Caspersen C, Christensen SB: A tool coming of age: thapsigargin as an inhibitor of sarcoendoplasmic reticulum $\mathrm{Ca}(2+)$-ATPases. Trends Pharmacol Sci 1998, 19:131-135.

doi:10.1186/1423-0127-18-16

Cite this article as: Li et al:: The functional expression of extracellular calcium-sensing receptor in rat pulmonary artery smooth muscle cells. Journal of Biomedical Science 2011 18:16.

\section{Submit your next manuscript to BioMed Central and take full advantage of:}

- Convenient online submission

- Thorough peer review

- No space constraints or color figure charges

- Immediate publication on acceptance

- Inclusion in PubMed, CAS, Scopus and Google Scholar

- Research which is freely available for redistribution

Submit your manuscript at www.biomedcentral.com/submit
C Biomed Central 